\title{
Antibiotic Susceptibility Pattern of Extended Spectrum Betalactamase (ESBL) Producers and other Bacterial Pathogens in Kano, Nigeria
}

\author{
Emmanuel O Nwankwo ${ }^{1 *}$, Nasiru S Magaji ${ }^{2}$ and Jamilu Tijjani ${ }^{3}$ \\ 1Department of Microbiology, Kogi State University, Anyigba, 2Department of Medical Microbiology and Parasitology, Aminu \\ Kano Teaching Hospital, 3Pathology Laboratory, Infectious Diseases Hospital, Kano, Nigeria
}

*For correspondence: Email: emmaonwubiko@yahoo.com; Tel: +234-8023309146

\begin{abstract}
Purpose: To evaluate the antibiotic susceptibility pattern of various bacterial pathogens including extended spectrum betalactamase (ESBL) producers in Kano, Nigeria.

Method: A total of 604 consecutive clinical samples obtained from Aminu Kano Teaching Hospital (AKTH), Kano between January and July 2010 were analyzed for bacterial pathogens using standard microbiological techniques for the isolation and identification of pathogens. Antibiotics susceptibility tests including, ESBL screening and confirmation, were carried out by disc diffusion technique using Clinical Laboratory Standard Institute (CLSI) criteria.

Results: Ten different types of bacteria genera were observed from nine different clinical samples. E. coli was the most frequently isolated bacteria (30.5 \%) followed by Staphylococcus aureus (21.3 \%). ESBL producers showed high-level resistance against the quinolones, aminoglycoside and cotrimoxazole but were sensitive to carbapenems and levofloxaccin. Non-ESBL organisms showed increased resistance to amoxicillin-clavulanate, ceftazidime, cotrimoxazole, tetracycline and amoxycillin. The prevalence of ESBL producers was $12.8 \%$. E. coli, Klebsiella pneumonia and Pseudomonas aeruginosa showed ESBL production of $17.3,14.9$ and $10.0 \%$, respectively.

Conclusion: The findings of this study suggest that regular surveys should be carried out in this locality to provide baseline data that would always be of clinical relevance in the treatment of patients and to detect the emergence of multiple antibiotic resistance strains.
\end{abstract}

Keywords: Antibiotic susceptibility, Multiple antibiotic resistance, Extended spectrum betalactamase, Bacterial pathogens

Tropical Journal of Pharmaceutical Research is indexed by Science Citation Index (SciSearch), Scopus, International Pharmaceutical Abstract, Chemical Abstracts, Embase, Index Copernicus, EBSCO, African Index Medicus, JournalSeek, Journal Citation Reports/Science Edition, Directory of Open Access Journals (DOAJ), African Journal Online, Bioline International, Open-J-Gate and Pharmacy Abstracts

\section{INTRODUCTION}

Before the discovery of penicillin, which initiated the antibiotic era, the prognosis for people with infectious diseases, such as bacterial pneumonia, tuberculosis and staphylococcal infections, was poor [1]. Today antibiotics are widely prescribed for various bacterial infections with a high degree of success. However, the unfortunate outcome of the wide-scale use of antibiotics is the development of antimicrobial resistance, an adaptive response in which microorganisms begin to tolerate an amount of drug to which it was previously susceptible. The development of mechanisms for circumventing or inactivating antibiotic drugs is due largely to the genetic versatility and adaptability of microbial populations [2]. 
Beta-lactam antimicrobial agents are the most common drugs for the treatment of bacterial infections and account for over $50 \%$ of global antibiotic consumption [3]. Bacterial resistance to B-lactam antibiotics has significantly increased in recent years and has been attributed to the spread of plasmid mediated B-lactamases. Some of these organisms have produced new forms of the older enzymes such as the extendedspectrum B-lactamases (ESBLs) that can hydrolyze newer celphalosporins and aztreonam [4].

Extended-spectrum b-lactamases (ESBLs) represent an important mechanism of resistance in Enterobacteriacaeae, because they inactivate penicillin, narrow- and extended-spectrum cephalosporins, and aztreonam [5]. This study is focused on the prevalence and antibiotic susceptibility pattern of ESBL producers in bacterial isolates of urogenital infections and other bacterial pathogens in Kano, Nigeria.

\section{EXPERIMENTAL}

\section{Media}

MacConkey agar, Blood agar base, Mueller Hinton agar, Salmonella Shigella agar were all manufactured by Oxoid, Bassingoke, United Kingdom. The antibiotic discs; ofloxacin $15 \mu \mathrm{g}$, ceftazidime $\quad 30 \quad \mu \mathrm{g}, \quad$ ceftriazone 30 $\mu \mathrm{g}$,ciprofloxacin $10 \mu \mathrm{g}$, amoxicillin/clavulanate 30 $\mu \mathrm{g}$, gentamicin $10 \mu \mathrm{g}$, levofloxacin $10 \mu \mathrm{g}$, amoxycillin $30 \mu \mathrm{g}$, erythromycin $15 \mu \mathrm{g}$, cotrimoxazole $25 \mu \mathrm{g}$, and cloxacillin $10 \mu \mathrm{g}$ (all from Abbot Laboratories, UK) were placed after the plates were confirmed to have dried, and incubated for 18 - 24 h. E. coli ATCC 25922, Pseudomonas aeruginosa ATCC 27853, S. aureus ATCC 25923 were used as control.

\section{Samples}

A total of 604 clinical samples as listed above obtained from patients at Amino Kano teaching Hospital from various service points between January and July 2010 were analyzed for bacterial pathogens by standard microbiological procedures [6].

The clinical samples consisted of the following: urine $(N=302)$, wound swab $(N=151)$, ear swabs $(N=78)$, catheter tips $(N=34)$, semen $(N$ $=3)$, endocervical swabs $(N=12)$, throat swabs $(\mathrm{N}=3)$ and umbilical cord swab $(\mathrm{N}=6)$.

The samples were inoculated on blood and MacConkey agar. Salmonella Shigella agar was included for enteric pathogens. All were incubated aerobically at $37{ }^{\circ} \mathrm{C}$ for $18-24 \mathrm{~h}$. Anaerobic culture was not carried out. Gram stain, motility and biochemical tests were used to identify the various isolates.

\section{Antibiotic susceptibility test}

This was carried out by disc diffusion technique, (WHO modified) in accordance with the CLSI criteria and interpreted accordingly [7]. Mueller Hinton culture plates were inoculated by dipping a sterile cotton wool swab into a suspension of the overnight growth of the organism prepared to the density of a Mc Farland no 0.5 opacity standard; excess liquid from the swab was expressed before inoculation by spread plate method.

\section{ESBL producers-screening and confirmation}

The isolates were tested against third generation cephalosporins (cefodoxime, cefotaxime and ceftriaxone) using Clinical Laboratory Standard Istitute (CLSI) recommended, WHO modified Kirby Bauer disc diffusion method [8]. Zone diameters were interpreted using the revised National Committee on Clinical Laboratory (NCCL) Standard document [14]. Isolates with reduced susceptibility to cefpodoxime $(\leq 17 \mathrm{~mm})$ cefotaxime $(\leq 27 \mathrm{~mm})$ and ceftriaxone $(\leq 25 \mathrm{~mm})$ were considered to be possible ESBL producers.

Phenotypic confirmation test was carried-out using Double Disc Synergy test. Disc containing the standard $10 \mathrm{ug}$ of cefpodoxime and $30 \mathrm{ug}$ of ceftazidime/ceftriaxone, are placed $15 \mathrm{~mm}$ apart (edge to edge); with amoxicillin-clavulanic acid disc containing 10 ug of the latter compound mounted exactly at their center. After $16-20 \mathrm{~h}$ of incubation at $35{ }^{\circ} \mathrm{C}$, any enhancement of the zone of inhibition between a beta-lactam disk and that containing the beta-lactamase inhibitor is indicative of the presence of an ESBL [9].

\section{Statistical analysis}

The data were computed as mean and standard deviation as well as in percentage. Chi-square analysis was carried out by Epi info Version 6 software. $P<0.05$ was accepted as statistically significant.

\section{RESULTS}

The age group prevalence of infected patients is presented on Table 1. The age group that had the highest number of isolates was $0-10$ years $(27.8 \%)$ while $>70$ years $(0.9 \%)$ had the least. 
The difference was statistically significant $X^{2}=$ 356.9, $\mathrm{df}=7, p<0.001$.

Table 1: Prevalence by age of infected patients

\begin{tabular}{lcc}
\hline Age (years) & $\mathbf{N}$ & Prevalence (\%) \\
\hline $0-10$ & 168 & 27.8 \\
$11-20$ & 71 & 11.8 \\
$21-30$ & 166 & 27.5 \\
$31-40$ & 78 & 12.9 \\
$41-50$ & 47 & 7.7 \\
$51-60$ & 35 & 5.8 \\
$61-70$ & 33 & 5.5 \\
$>70$ & 6 & 0.9 \\
\hline
\end{tabular}

$\mathrm{X}^{2}=356.9, \mathrm{df}=7, p<001$

Table 2 shows the distribution of bacterial pathogens by clinical samples and gram staining reactions. $75 \%$ of the isolates showed gram negative result while $24.8 \%$ were Gram positive cocci. Urine sample constituted the largest number of specimens (50 \%) followed by wound swab (25\%). E. coli was the most frequently isolated organism $(30.5 \%)$ followed by $S$. aureus (21.3\%).

The antibiotic susceptibility data for the bacterial pathogens, which shows high level of resistance against various antibiotics, are presented in Table 3.

Most pathogens were resistant to commonly used antibiotics such as tetracycline, cotrimoxazole and amoxycillin. E. coli and Klebsiella pneumonia showed 14 and $16 \%$ susceptibility respectively against amoxicillin/clavulanate and 43 and $21 \%$ respectively against ceftazidime. However, ceftriaxone, gentamicin and levofloxacin showed over $60 \%$ susceptibility against most bacterial pathogens.
Table 4 shows the percentage prevalence of extended spectrum beta-lactamase producers among urogenital pathogens.

E. coli had the highest prevalence of $17.3 \%$ followed by Klebsiella pneumonia $14.9 \%$ while the least was Proteus vulgaris $2.4 \%$. The difference however, was not statistically significant $\left(X^{2}=9.22\right.$, df $\left.=4, p=0.05\right)$.

The antibiotic susceptibility pattern of ESBLs against six antibiotics is presented in Table 5 . Besides exhibiting high level resistance against the cephalosporins, these pathogens also show resistance to other groups of antibiotics such as the aminoglycoside, fluoroquinolones and cotrimoxazole.

However, the cabapenemes and levofloxacins showed encouraging results above $60 \%$ (57 - 69 $\%)$.

\section{DISCUSSION}

The prevalence of resistance to antibiotics varies greatly from one geographical area to another as well as between hospitals within community, mainly because of the differences in antimicrobial usage and infection control practices [10].

The age group prevalence of high infectious rate observed in infants and older children when exposed to bacterial pathogens could be attributed to their low level of immunity, other researchers made similar observations in their reports [11]. The majority of the bacterial isolates $75.2 \%$, observed in the study were Gram negative bacilli mainly of the Enterobacteriaceae.

Table 2: Distribution of bacterial pathogens by clinical samples and Gram-staining reactions

\begin{tabular}{|c|c|c|c|c|c|c|c|c|c|c|c|}
\hline Isolate & UR & CT & ES & WS & ST & ECS & TS & SM & UBC & Total & $\%$ \\
\hline \multicolumn{12}{|l|}{ Gram-negative } \\
\hline E. coli & 136 & 9 & 20 & 15 & 0 & 5 & 0 & 0 & 1 & 186 & 30.5 \\
\hline K. pneumonia & 58 & 3 & 10 & 10 & 0 & 6 & 1 & 2 & 0 & 90 & 14.8 \\
\hline P. mirabilis & 25 & 3 & 10 & 10 & 0 & 1 & 0 & 0 & 0 & 49 & 9.0 \\
\hline P. vulgaris & 39 & 0 & 7 & 2 & 0 & 0 & 1 & 1 & 0 & 50 & 8.2 \\
\hline$P$. aeruginosa & 24 & 9 & 16 & 10 & 0 & 0 & 1 & 0 & 0 & 60 & 9.8 \\
\hline Enteropathic E. coli & 0 & 0 & 0 & 0 & 10 & 0 & 0 & 0 & 0 & 10 & 1.6 \\
\hline Salmonella typhi & 0 & 0 & 0 & 0 & 5 & 0 & 0 & 0 & 0 & 5 & 0.8 \\
\hline Enterobacter Spp & 2 & 0 & 0 & 0 & 0 & 0 & 0 & 0 & 0 & 2 & 0.3 \\
\hline M. morgani & 1 & 0 & 0 & 0 & 0 & 0 & 0 & 0 & 0 & 1 & 0.2 \\
\hline S. marcescens & 1 & 0 & 0 & 0 & 0 & 0 & 0 & 0 & 0 & 1 & 0.2 \\
\hline \multicolumn{12}{|l|}{ Gram-positive } \\
\hline E. faecalis & 16 & 0 & 0 & 4 & 0 & 0 & 0 & 0 & 0 & 20 & 3.3 \\
\hline S. aureus & 0 & 10 & 15 & 100 & 0 & 0 & 0 & 0 & 5 & 130 & 21.3 \\
\hline Total & 302 & 34 & 78 & 151 & 15 & 12 & 3 & 3 & 6 & 604 & \\
\hline
\end{tabular}

Key: UR = urine, CT = catheter tip, ES = ear swab, WS = wound swab, ST = stool, ECS = endocervical swab, TS $=$ throat swab, $\mathrm{SM}=$ semen, $\mathrm{UBC}=$ umbilical cord swab 


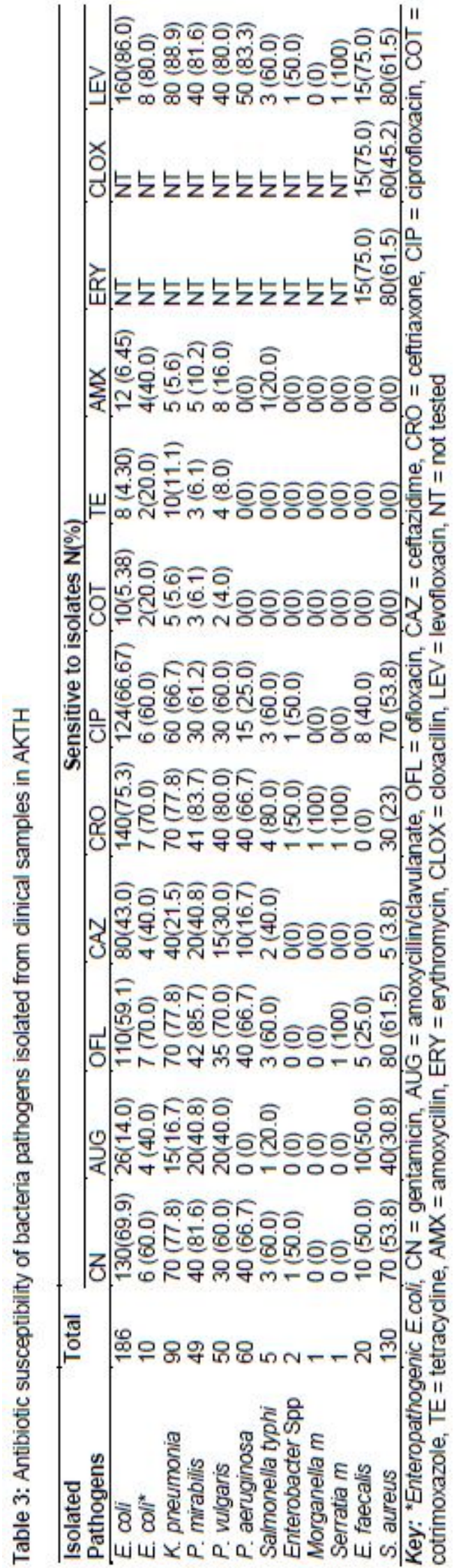

This is in agreement with the reports of other researchers [12]. E. coli (30.5\%) was the most frequently isolated. It also accounted for most of all urinary isolates giving $45.0 \%$. This observation is in agreement with the findings of other research workers [13]. The preponderance of this organism may be due to the fact that it constitutes a large proportion of the intestinal flora and with low hygienic practices, it will be expected to be isolated in diseases such as urinary tract infection, wound infections and other bacterial infections.

The prevalence of ESBL producers in this study was $12.8 \%$, which is higher than an earlier study in Kano [14] that reported $9.25 \%$, but much lower than a report of $36.2 \%$ from Ebonyi State in Nigeria [15]. However, these results are higher than the report of $2.6 \%$ from researchers in Bosnia and Herzegovina [16], and also $8.9 \%$ from Saudi Arabia [17]. These may be attributed to different cultures of antibiotic usage in states where studies were carried out.

E. coli and Klebsiella pneumoniae showed ESBLs prevalence of $17.3 \%$ and $14.9 \%$ respectively in the present study. These values were lower than the reports from India [18]. However, both reports are at variance with another report from Nigeria [19] in which Klebsiella pneumoniae had ESBL prevalence of $35.3 \%$ while $E$. coli had $27.3 \%$. The antibiotic susceptibility of ESBL $E$. coli was $46.1,7.6,30.8$ and $57.7 \%$ when tested against gentamicin, cotrimoxazole, ciproflaxacin and levofloxacin respectively. Against imipenem and meropenem ESBL producing $E$. coli showed an antibiotic susceptibility of $69.2 \%$ and $61.5 \%$, respectively. Other researchers [20] also reported encouraging antibiotic susceptibility result with imipenem and meropenem.

The predominating presence of $S$. aureus (76.9 $\%$ ) on the isolates in wound swab, agrees with earlier reports [21]. It is important to mention that its high level resistance characteristics observed in this study is also in agreement with other reports [22]. S. aureus showed antibiotic susceptibility of $30.8,3.8,23,0,0,0$ and $45.2 \%$ when tested with amoxicillin/clavulanate, ceftazidime, ceftriaxone, cotrimoxazole, tetracyclin, amoxicillin and cloxacillin. E. coli was also observed to have shown very poor susceptibility to all the antibiotics mentioned which are all routine and commonly used drugs 
Table 4: Prevalence of extended-spectrum betalactamase (ESBL) producers among Gram-negative urogenital pathogens

\begin{tabular}{|c|c|c|c|c|}
\hline Bacteria isolate & No. of isolates screened & Positive & Negative & $\begin{array}{c}\text { Prevalence } \\
(\%)\end{array}$ \\
\hline E. coli & 150 & 26 & 124 & 17.3 \\
\hline Klebsiella pneumoniae & 67 & 10 & 57 & 14.9 \\
\hline Proteus mirabilis & 29 & 2 & 27 & 6.8 \\
\hline Proteus vulgaris & 41 & 1 & 40 & 2.4 \\
\hline Pseudomonas aeruginosa & 33 & 2 & 31 & 6.0 \\
\hline Total & 320 & 41 & 280 & 12.8 \\
\hline
\end{tabular}

$\mathrm{X}^{2}=9.22, \mathrm{df}=4, p=0.05$

Table 5: Antibiotic susceptibility pattern of ESBL producers

\begin{tabular}{llllllll}
\hline Pathogen & No. of & \multicolumn{5}{c}{ Sensitive isolates N(\%) } \\
\cline { 3 - 8 } & isolates & $\mathbf{C N}$ & COT & CIP & IMP & MEP & LEV \\
\hline E. coli & 26 & $12(46.1)$ & $2(7.6)$ & $8(30.8)$ & $18(69.2)$ & $16(61.5)$ & $15(57.7)$ \\
Klebsiella pneumonia & 10 & $5(50)$ & $0(0)$ & $4(40)$ & $7(70)$ & $6(60)$ & $6(60)$ \\
Proteus mirabilis & 2 & $0(0)$ & $0(0)$ & $0(0)$ & $0(0)$ & $1(50)$ & $1(50)$ \\
Proteus vulgaris & 1 & $0(0)$ & $0(0)$ & $0(0)$ & $0(0)$ & $0(0)$ & $1(100)$ \\
Pseudomonas aeruginosa & 2 & $1(50)$ & $0(0)$ & $0(0)$ & $1(50)$ & $0(0)$ & $1(50)$ \\
\hline
\end{tabular}

Key: $C N=$ gentamicin, $C O T=$ cotrimoxazole, $C I P=$ ciprofloxacin, $I M P=$ imipenem, $M E P=$ meropenem, $L E V=$ levofloxacin

that are completely losing their efficacy against increasing wave of bacterial resistance.

Many clinical laboratories (as well as the wider medical community) are not fully aware of the importance of ESBLs and how to detect them; laboratories may also lack the resources to curb the spread of these resistance mechanisms [23]. This ignorance and possible financial constraints may be responsible for the continuous dissemination of ESBLs worldwide.

Despite the rapidity with which new chemotherapeutic agents are introduced, bacteria have shown a remarkable ability to develop resistance to these agents. In view of the steady rise in bacteria resistance to antibiotics, it has become very important to carry out in vitro antimicrobial susceptibility testing before prescription.

\section{CONCLUSION}

Regular studies of the antibiotic susceptibility pattern of isolates commonly observed in a locality will guide therapeutic judgment and enhance antibiotic prescribing. Such surveys will yield the first clue when multi drug resistant isolates are encountered to prevent therapeutic failures that could be fatal in the management of patients.

\section{ACKNOWLEDGEMENT}

We are grateful for the assistance of members of staff, Microbiology Laboratory Department, AKTH.

\section{REFERENCES}

1. Nwadioha SI, Nwokedi EOP, Ikeh I, Egesie J, Kashibu E. Antibiotic susceptibility pattern of uro-pathogenic bacterial isolates from AIDS patients in a Nigerian tertiary hospital. J Med Med Sci. 2010; 1(11): 530534.

2. Sule WF, Adige AA, Abubakar MJ, Ojezele MO: Antimicrobial resistance of clinical isolates of $S$. typhi in Anyigba, Kogi state. Clo Adv Res J Microbiol. 2012; 1(4): 057-061

3. Kotra LP, Samama J, Mobashery S. $\beta$-lactamases and resistance to $B$-lactam antibiotics, In Lewis, $K$., Salyers, A. A., Tabar, H. W. and Wax, R. G. Eds. Bacterial resistance to antimicrobials. Mercel Decker, New York 2002: 123-160.

4. Paterson DL, Bonomo RA. Extended spectrum Blactamases: Clinical update. Clin Microbiol Rev. 2005; 18(4): 657-686.

5. Cao V, Lambert T, Nhu DQ, Loan HK, Hoang NK, Alert $G$, Courvalin P. Distribution of Extended-spectrum Blactamases in clinical isolates of Enterobacteriaceae in Vietnam. Antimicrob Agents Chemother 2002; 46: 3739-3743.

6. Cheesebrough M. District laboratory practice for tropical countries, Cambrigde University press, UK 2004; 2: 180-197.

7. Clinical Laboratory Standard Institute. Performance standard for antimicrobial disc susceptibility test; Approved standard-9th Ed. Supplement M2-A9, 2006;26(1) 
8. Lalitha MK. Manual on Antimicrobial Susceptibility Testing. Department of Microbiology Christian Medical College, Vellore, Tamil Nadu 2001; 10-13.

9. Coudron PE, Moland ES, Sanders CC. Occurrence and detection of Extended-Spectrum B-lactamases in members of the Family Enterobacteriaceae at a Veterans Medical Centre: Seek and you May Find. J Clin Microbiol. 1997; 35: 2593-2597.

10. Manges AR, Johnson JR, Foxman B, O'Bryan TO, Fullerton KE, Riley LW. Widespread distribution of urinary tract infections caused by a multidrugresistant Escherichia coli clonal group. N Engl J Med 2001; 345: 1007-1013.

11. Nwankwo EOK and Salisu AD. Bacteriology of chronic discharging Ears of patients in Kano, Nigeria. J Med Lab Sci. 2005; 14(1): 57-62.

12. Okwori EE, Nwadioha SI, Nwokedi EoP, Odimayo M, Jombo GTA. Bacterial pathogens and their antibiotic susceptibility pattern in Idoma community, Benue state Nigeria. Emedpub International Infect Dis 2011; 1: 5 .

13. Abdullahi SK, Opajobi SO, Takalmawa HU, Nwankwo EOK, Arzai AH, Haliru AH and Hamza S. prevalence of Urinary tract infection due to E. coli at Aminu Kano Teaching Hospital, Kano, Nigeria. BEST journal 2006; 3(2): 144-147

14. Yusha'u M, Olonitola SO, Aliyu BS. Prevalence of Extended-spectrum B-lactamases (ESBLs) among members of the Enterobactericeaea isolates obtained from Mohammed Abdullahi Wase Specialist Hospital, Kano, Nigeria. Int J Pure Appl Sci 2007; 1(3): 42-48

15. Iroha E, Amadi A, Agabus, Oji A.: Susceptibility pattern of Extended-spectrum Beta-lactamase producing Klebsiella pneumonia from clinical isolates. $J$ Microbiol. 2008; 5(2): 34-39
16. Uzunovie-Kamberovis $S$, Saric $D$, Sestic $S$, Communityacquired urinary tract infection by extended-spectrum beta-lactase-producing Enterobactericeae in ZenicaDoboj Canton, Bosnia and Herzegovina. Medicinski glasnik. 2006; 3(2): 46-52.

17. Babypadmini S, Appalaraju B. Extended spectrum Betalactamases in Urinary Isolates of Escherichia coli and klebsiella pneumoniae: Prevalence and Susceptibility pattern in Tertiary Hospital. J Med Microbiol. 2004; 22(3): $172-174$

18. Olonitola OS, Olayinka AT, Inabo HI, Shaibo AM. Short Communication: production of ESBL of Urinary Isolates of E. coli and Klebsiella pneumonia in Ahmadu Bello University Teaching Hospital, Zaria, Nigeria. Int J Biol Chem Sci. 2007; 1(2): 181-185.

19. Jacob GA, Carreras I, Activities of beta-lactam antibiotics against E.coli strains producing extended-apectrum betalactamases. Antimicrob. Agents Chemother. 1990; 34(5): 858-862.

20. Isibor JO, Oseni A, Eyaufe A, Osagie R, Turay $A$. incidence of aerobic bacteria and Candida albicans in post-operative wound infections Afr J Microbiol Res. 2008; 2: 288-291

21. Santos KR, Fonseca LS, Bravo Neto GP, Gontigo filho $P P$. Surgical site infection rates aetiology and resistance patterns to antimicrobials among strains isolated at Rio de Janeiro University Hospital J. Hosp. Infect. 1997; 4: 217-270.

22. Thomson K. Controversies about extended-spectrum and AmpC beta-lactamases. Emerg Infect Dis 2001; 7: 333-336.

23. Kader AA, Angamuthu K. Extended-spectrum betalactamases in urinary isolates of Escherichia coli, Klebsiella pneumonia and other gram-negative bacteria in a Hospital in Eastern Province, Saudi Arabia. Saudi Med J. 2005; 26(6): 956-959. 